\title{
MEASURING A CUSTOMER INTIMACY CULTURE IN A VALUE DISCIPLINE CONTEXT
}

\author{
A POTGIETER \\ G ROODT \\ gr@ujhb.ac.za \\ Department of Human Resources Management \\ Rand Afrikaans University
}

\begin{abstract}
The purpose of the study was to evaluate a questionnaire for the assessment of a customer intimacy culture in the value discipline context. The main survey was completed by using a convenience sample of permanent employees $(\mathrm{N}=200)$ at line, middle and top management levels of an organisation in the entertainment industry. This sample was taken from staff on structured developmental paths, while attending scheduled training events. The 169 completed questionnaires that were returned were used for the final data analyses. Owing to the small sample size, an adapted procedure for first- and second-level factor analyses was used, followed by an iterative item analysis. The preliminary findings suggest that the questionnaire can be applied for assessing customer intimacy cultures.
\end{abstract}

\section{OPSOMMING}

Die doel van hierdie studie was om 'n vraelys te evalueer vir die beoordeling van 'n kliëntintimiteitskultuur in die waardedissipline konteks. Die hoofopname is voltooi deur ' $n$ gerieflikheidsteekproef $(\mathrm{N}=200)$ van permanente personeel in lyn, middel- en topbestuursvlakke van 'n organisasie in die vermaaklikheidsbedryf te gebruik. Dié steekproef is geneem vanuit personeel in gestruktureerde ontwikkelingspaaie wat geskeduleerde opleidingsgeleenthede bygewoon het. Die 169 voltooide vraelyste wat terugontvang is, is vir die finale dataontleding gebruik. Weens die klein steekproefgrootte, is 'n aangepaste prosedure vir eerste- en tweedevlakfaktorontleding gebruik, gevolg deur 'n iteratiewe itemontleding. Die voorlopige bevindinge dui daarop dat die vraelys toegepas kan word vir die beoordeling van 'n kliëntintimiteitskultuur.

The role of value disciplines in establishing a customer service culture

In today's ever-changing organisational environment, the strategic link to organisational effectiveness and competitiveness is also based on meeting and exceeding the needs and expectations of customers. To enable organisations to do so, they need to understand what the value orientation of their specific customer base is. In simpler terms, what would be perceived as value adding by the customers specific to their sector and product or service? Organisations that focus their strategic directions and efforts on the provision of an overarching customer service experience are those that become world-class.

In the World Competitiveness Report (Garelli, 1999), South Africa was ranked 47 th out of 47 participating countries when evaluated in terms of creating customer value. South African organisations can no longer function within time capsules where the isolation of the past has shielded them from worldclass competitive forces. Globalisation and the changes in the new economic order have forced South African organisations to become more customer needs driven.

Treacy and Wiersema (1993; 1995) have identified three value disciplines on which organisations should focus. Adopting these value orientations and aligning them to the overall strategic direction and functioning of the organisation will enable them to meet and exceed customer expectations and thus add "real" value to the customer's experience.

The three value disciplines are described as follows by different authors:

Operational excellence means providing customers with reliable products or services at competitive prices and delivered with minimal difficulty or inconvenience (French, 1995; Gubman, 1995; Treacy \& Wiersema, 1993; Zemke, 1993).

Customer intimacy means segmenting and targeting markets precisely and then tailoring offerings to match exactly the demands of those niches. Companies that excel in customer

Requests for copies should be addressed to: A Potgieter, Department of Human

Resource Management, RAU University, PO Box 524, Auckland Park, 2006 intimacy combine detailed customer knowledge with operational flexibility so they can respond quickly to almost any need, from customising a product to fulfilling special requests (French, 1995; Gubman, 1995; Treacy \& Wiersema, 1993; Zemke, 1993).

Product leadership means offering customers leading-edge products and services that consistently enhance the customer's use or application of the product, thereby making their rivals' goods obsolete (French, 1995; Gubman, 1995; Treacy \& Wiersema, 1993; Zemke, 1993).

Determining the preferred value orientation of the organisation's customers is only the starting point. Leading-edge organisations not only identify the unique value they can add to their customers, but they also ensure that they strategically align their processes and people practices around the delivery thereof.

In all three of the disciplines described above, the operational model that the organisation is following will include enabling and driving factors around the specifics required by the value adding needs. In operational excellence the main focus will be process and systems based, in customer intimacy it will be relationship management based and in product leadership it will be driven by innovation, research and development (Treacy \& Wiersema, 1993).

The strategic planning and management of products, people practices and processes of an organisation should thus be organised into a value delivery system embedded in a customer service culture. Treacy and Wiersema (1995) highlight the fact that business strategies should be looked at from the viewpoint of how/where and what the customer regards as value. This strategic value delivery system should focus the organisation within this required customer preference, while still achieving parity with industry standards in the other two value disciplines.

Organisations that want to align their people practices, processes and products (embedded in a customer service culture) strategically need firstly to determine the value orientation of their customer base. To ensure effectiveness in providing the value the customers prefer, organisations need to have the competency profile, enabling processes and organisational 
systems to achieve the required results (cf. Dannhauser \& Roodt, 2001). Thus, organisational focus is best applied if the organisation strives to add maximum value by aligning its core strategies around this preference by means of its supporting culture, processes, methods and structures.

Each of the three said value disciplines demand a different core organisational capability. These core capabilities are presented in Table 1. The ten key people strategies (dimensions A-J) are also presented in the context of each value discipline. These ten people strategies are based on the initial five strategies of a model developed by Gubman (1995). The framework presented in Table 1 thus serves as the theoretical basis for the development of the comprehensive Culture Assessment Questionnaire $(\mathrm{CAQ})$ focusing on all three value disciplines. The primary objective of the current study is to evaluate the section of the CAQ that focuses only on the customer intimacy value discipline.

TABLE 1

KeY PEOPLe STRATegIES IN THE VALUe DisCIPLINES

\begin{tabular}{|c|c|c|c|}
\hline & \multicolumn{3}{|c|}{ VALUE DISCIPLINES } \\
\hline & $\begin{array}{l}\text { Operational } \\
\text { Excellence (OE) }\end{array}$ & $\begin{array}{l}\text { Product } \\
\text { Leadership (PL) }\end{array}$ & $\begin{array}{l}\text { Customer } \\
\text { Intimacy (CI) }\end{array}$ \\
\hline $\begin{array}{l}\text { CORE } \\
\text { ORGANISATIONAL } \\
\text { CAPABILITY }\end{array}$ & $\begin{array}{l}\text { Providing } \\
\text { reliable products } \\
\text { or services at } \\
\text { competitive } \\
\text { prices and } \\
\text { delivered with } \\
\text { minimal } \\
\text { difficulty and } \\
\text { inconvenience. }\end{array}$ & $\begin{array}{l}\text { Providing leading } \\
\text { edge products } \\
\text { and services, } \\
\text { consistently } \\
\text { enhancing the } \\
\text { use of the } \\
\text { product/service - } \\
\text { making rivals' } \\
\text { goods obsolete. }\end{array}$ & $\begin{array}{l}\text { Segmenting and } \\
\text { targeting markets } \\
\text { precisely, and } \\
\text { tailoring offerings } \\
\text { to match exactly } \\
\text { the demands of } \\
\text { those niches. } \\
\text { Customer } \\
\text { sensitivity and } \\
\text { flexibility. }\end{array}$ \\
\hline \multicolumn{4}{|l|}{ DIMENSIONS } \\
\hline $\begin{array}{l}\text { A: Personnel } \\
\text { Strategy }\end{array}$ & $\begin{array}{l}\text { Emphasize } \\
\text { motivation and } \\
\text { corporate spirit. } \\
\text { Build teams that } \\
\text { deliver cost- } \\
\text { effective value, } \\
\text { and high quality, } \\
\text { user-friendly } \\
\text { products and } \\
\text { services. }\end{array}$ & $\begin{array}{l}\text { Provide a } \\
\text { comfortable, } \\
\text { positive, creative } \\
\text { environment. } \\
\text { Provide basic } \\
\text { needs. Remove } \\
\text { them from HR } \\
\text { policies and } \\
\text { management } \\
\text { concerns. Do } \\
\text { not differentiate } \\
\text { between people. }\end{array}$ & $\begin{array}{l}\text { "Satisfied } \\
\text { employees satisfy } \\
\text { customers." Rely } \\
\text { on values to } \\
\text { shape culture and } \\
\text { messages. Promote } \\
\text { relationship } \\
\text { building as } \\
\text { priority. }\end{array}$ \\
\hline B: Organising & $\begin{array}{l}\text { Teams: Project, } \\
\text { process, product } \\
\text { or customer } \\
\text { based. } \\
\text { Knowledge is } \\
\text { shared. Best } \\
\text { practice } \\
\text { applications. }\end{array}$ & $\begin{array}{l}\text { Product } \\
\text { groupings based } \\
\text { on creative } \\
\text { structure - team } \\
\text { or individual. } \\
\text { Separate sales } \\
\text { and creation } \\
\text { functions. }\end{array}$ & $\begin{array}{l}\text { Customer needs } \\
\text { driven, but can } \\
\text { be individual or } \\
\text { team based. } \\
\text { Strong focus on } \\
\text { relationship } \\
\text { building. All } \\
\text { individuals } \\
\text { constantly selling } \\
\text { to customers - } \\
\text { improving } \\
\text { relations. }\end{array}$ \\
\hline $\begin{array}{l}\text { C: Personnel } \\
\text { Procurement }\end{array}$ & $\begin{array}{l}\text { Criteria: Logical, } \\
\text { efficient, cost } \\
\text { conscious, } \\
\text { resourceful, } \\
\text { analytical, } \\
\text { following } \\
\text { procedures, } \\
\text { initiating self- } \\
\text { growth, short- } \\
\text { term focus, } \\
\text { systematic, team } \\
\text { player, good } \\
\text { communicator, } \\
\text { detail oriented, } \\
\text { problem solver. }\end{array}$ & $\begin{array}{l}\text { Criteria: Courage, } \\
\text { innovation, } \\
\text { creativity, high } \\
\text { technological } \\
\text { development, } \\
\text { long term focus, } \\
\text { future focus, } \\
\text { possibility } \\
\text { focused, pride in } \\
\text { being first in } \\
\text { product quality, } \\
\text { getting it right. }\end{array}$ & $\begin{array}{l}\text { Criteria: Highly } \\
\text { responsive, } \\
\text { excellent } \\
\text { listening skills, } \\
\text { empathetic, } \\
\text { consultative, } \\
\text { perceptive, } \\
\text { flexible values } \\
\text { driven. Good } \\
\text { communication } \\
\text { and technical } \\
\text { skills. Able to } \\
\text { assess needs. } \\
\text { Spontaneous } \\
\text { problem-solvers, } \\
\text { understand } \\
\text { motivation. Long- } \\
\text { term relationship } \\
\text { focus. }\end{array}$ \\
\hline
\end{tabular}

\begin{tabular}{|c|c|c|c|}
\hline D: Development & $\begin{array}{l}\text { Emphasis on } \\
\text { methods } \\
\text { learning, team } \\
\text { behaviours, } \\
\text { process } \\
\text { management and } \\
\text { control, product, } \\
\text { time and quality } \\
\text { control. }\end{array}$ & $\begin{array}{l}\text { Emphasis on } \\
\text { technical and } \\
\text { creative training. } \\
\text { Research skills, } \\
\text { product } \\
\text { development and } \\
\text { team processes. }\end{array}$ & $\begin{array}{l}\text { Emphasis on } \\
\text { organisational } \\
\text { values, } \\
\text { relationship } \\
\text { skills, } \\
\text { communication } \\
\text { skills, planning, } \\
\text { knowledge } \\
\text { sharing, e.g. new } \\
\text { products or } \\
\text { services. }\end{array}$ \\
\hline E: Achievement & $\begin{array}{l}\text { Measures: Hard } \\
\text { numbers, results, } \\
\text { on time, on } \\
\text { budget, project } \\
\text { completion and } \\
\text { quality, cost } \\
\text { reduction. Peer } \\
\text { feedback on } \\
\text { team behaviours. }\end{array}$ & $\begin{array}{l}\text { Measures: } \\
\text { Contribution } \\
\text { made to new and } \\
\text { innovative } \\
\text { product/service } \\
\text { development. } \\
\text { Revenues from } \\
\text { new products, } \\
\text { shipment } \\
\text { statistics. }\end{array}$ & $\begin{array}{l}\text { Measures: } \\
\text { Relationship } \\
\text { productive } \\
\text { behaviours. New } \\
\text { customers gained, } \\
\text { customers } \\
\text { retained and } \\
\text { lateral selling. }\end{array}$ \\
\hline F: Remuneration & $\begin{array}{l}\text { Strategic } \\
\text { approach. Pay for } \\
\text { performance, } \\
\text { individual and } \\
\text { team basis, below } \\
\text { market base plus } \\
\text { incentives. } \\
\text { Variable } \\
\text { incentives based } \\
\text { on organisation, } \\
\text { unit or team } \\
\text { results. Profit } \\
\text { sharing. }\end{array}$ & $\begin{array}{l}\text { Rewards not } \\
\text { used as a } \\
\text { strategic tool, } \\
\text { no direct } \\
\text { differentiation. } \\
\text { Rewards kept } \\
\text { neutral. Salaries } \\
\text { and benefits } \\
\text { above market. } \\
\text { Profit sharing - } \\
\text { equal } \\
\text { distribution. } \\
\text { Defined benefit } \\
\text { plans. }\end{array}$ & $\begin{array}{l}\text { Rewards tied to } \\
\text { values. Based on } \\
\text { behavioural, } \\
\text { subjective } \\
\text { assessments. } \\
\text { Profit sharing - } \\
\text { individual } \\
\text { contribution } \\
\text { recognised. Broad } \\
\text { benefit choices. }\end{array}$ \\
\hline G: Strategy & $\begin{array}{l}\text { Process and } \\
\text { systems based. }\end{array}$ & $\begin{array}{l}\text { Innovation, } \\
\text { research and } \\
\text { development } \\
\text { based. }\end{array}$ & $\begin{array}{l}\text { Relationship } \\
\text { management } \\
\text { based. }\end{array}$ \\
\hline H: Core Values & $\begin{array}{l}\text { Reliability, } \\
\text { accessibility, } \\
\text { quality, market } \\
\text { leadership. }\end{array}$ & $\begin{array}{l}\text { Change } \\
\text { sensitivity, } \\
\text { creativity, focus } \\
\text { on internal value } \\
\text { adding. }\end{array}$ & $\begin{array}{l}\text { Customer } \\
\text { centricity and } \\
\text { sensitivity to } \\
\text { customer } \\
\text { expectations. }\end{array}$ \\
\hline I: Core Abilities & $\begin{array}{l}\text { Consistency in } \\
\text { provision, follow } \\
\text { up and support. }\end{array}$ & $\begin{array}{l}\text { Market leadership } \\
\text { and continuous } \\
\text { benchmarking. }\end{array}$ & $\begin{array}{l}\text { Customer } \\
\text { relationship } \\
\text { building and } \\
\text { retention } \\
\text { strategies. }\end{array}$ \\
\hline J: Business Model & $\begin{array}{l}\text { Structured - } \\
\text { process driven. } \\
\text { Functional } \\
\text { groupings }\end{array}$ & $\begin{array}{l}\text { Flexible - change } \\
\text { sensitive. Project } \\
\text { team groupings. }\end{array}$ & $\begin{array}{l}\text { Flexible - people } \\
\text { centred, "flat" } \\
\text { organisation. }\end{array}$ \\
\hline
\end{tabular}

From Table 1 one can also infer that companies adhering to a particular value discipline have different modus operandi in differentiating themselves from other companies in the other two value disciplines. These modus operandi thus serve as the basis for establishing a unique organisational culture.

A review of the literature revealed that the construct of 'organisational culture' remains one of the most contested areas of academic inquiry in the broader field of organisational studies (cf. Du Toit, 2003; Petkoon, 2003; Smith, 2003). Organisational culture is characterised by competing definitions, epistemologies and research paradigms. Controversies exist about virtually all aspects of this construct, including the mechanics and the extent of its contribution to organisational performance (Erwee, Lynch, Millitt, Smith \& Roodt, 2001).

Despite these differences, a seemingly widely accepted definition of culture is the one by Schein $(1985$, p. 9):

A pattern of basic assumptions - invented, discovered or developed by a given group as it learns to cope with its problems of external adaptation and internal integration - that has worked well enough to be considered valid and therefore, to be taught to new members as the correct way to perceive, think and feel in relation to those problems. 
Prominent researchers such as Schein, DeLisi, Kampas and Sonduck (2003) have pointed out that organisational culture plays an important role in supporting and executing organisational strategies. If an organisation does not succeed in developing and establishing a supportive culture, the organisation will most probably fail.

Within the strategic framework of the value disciplines, it becomes imperative that an organisation should develop a culture that will support the selected value discipline. There should be an alignment between the strategic intent and the desired organisational culture and this process should be managed consciously and actively. This implies that managers should know the required key characteristics that they want to foster and grow. Organisational culture assessment instruments can play a key role in this process.

One way of classifying organisational culture assessment instruments is to distinguish between objective and subjective organisational culture measures. Subjective organisational culture is assessed, based on own personal perceptions, attitudes and experiences. Objective organisational culture, on the other hand, is assessed by means of objective organisational characteristics. The instrument (the CAQ) used in the current study is based on the latter approach. The objective approach has some limitations, as was pointed out by research conducted on a different instrument, the Culture Assessment Instrument (CAI) of Martins (1989) (cf. Du Toit, 2003; Petkoon, 2003).

The underlying theoretical model of the CAI (cf. Du Toit, 2003; Martins, 1989; Petkoon, 2003) also focused on different organisational sub-systems such as organisational goals and strategies, human-social processes, structures, tasks and technologies (comparable to those presented in Table 1). The level of assessing these characteristics is normally on the visible first level of Schein's (1985) typology of culture. The benefits of quantitative measures of organisational culture are clear (cf. Du Toit, 2003; Petkoon, 2003), but also have some limitations in the sense that they do not tap into the deeper levels of Schein's typology of culture, that may result in low levels of discriminant validity (the ability to discriminate between the cultures or sub-cultures of organisations). This may also be the case with the CAQ.

The problem of low discriminant validity seems to be that organisations possess systems, procedures and processes that have similar characteristics. There may be a possibility that organisational culture assessment instruments that follow the objective approach are not sensitive enough to register the finer nuances of these differences in organisational structures, processes and systems. This should be kept in mind when designing a culture assessment instrument that will also comply with the requirements of discriminant validity (cf. Du Toit, 2003; Petkoon, 2003). Discriminant validity is an important facet of validity that will enable instruments to distinguish successfully between different organisations' cultures and sub-cultures based on their key characteristics such as processes, structures and systems (cf. Du Toit \& Roodt, 2003; Petkoon \& Roodt, 2004). A recent overview of organisational culture research (Ashkanasy, Wilderom \& Peterson, 2000) indicates that discriminant validity, as an important facet of validity, was not addressed at all. The secondary objective of the study may shed some light on this aspect of the CAQ.

Purpose of the study

Given the above discussion, the objectives of the study are stated as follows:

- The primary purpose of the study is to evaluate a questionnaire (the CAQ) for the assessment of a customer intimacy culture in the value discipline context.
- A secondary objective of the study is to assess whether the instrument could discriminate between culture mean scores of groups created on the basis of selected biographical variables.

\section{RESEARCH DESIGN}

\section{Research approach}

The research approach followed in this study was quantitative and cross-sectional by using a typical, non-random field survey method. The data analysis conducted was correlational and $e x$ post facto (identifying relationships retrospectively) by nature, using the primary data generated by the survey. The process followed for collecting the data was an anonymous, unlinked, survey conducted among the line, middle and top management levels of the organisation. Surveys were completed in a training environment as part of internal developmental sessions over a period of two months at the start of 2003.

\section{Research methodology}

The research methodology followed in this study will be discussed under the following four headings:

Research participants

A population of 200 employees of a company in the entertainment industry (adopting a customer intimacy strategy) was targeted for this field survey. A relatively high response rate of about $70 \%$ yielded 139 completed questionnaires and therefore forced the researchers to supplement the numbers with about 33 questionnaires obtained through other surveys. A total number of 169 usable questionnaires was included in the final analysis.

Most of the respondents were under the age of $30(59,7 \%)$ and only $10,7 \%$ were over the age of 40 . This distribution is typical for this kind of industry. The organisation has only been in existence for four years, but most of these individuals have come from other organisations in the industry and were placed directly into supervisory or management positions based on experience, not performance. This is not unique, as the industry has only been deregulated since 1997 and most of the role players in the industry are relatively new.

TABLE 2

RESPONDENTS' BIOGRAPHICAL PARTICULARS

\begin{tabular}{|c|c|c|}
\hline Biographical variable & Count & Percentage \\
\hline \multicolumn{3}{|l|}{ AGE } \\
\hline Up to 30 years & 101 & $59,7 \%$ \\
\hline $31-40$ & 50 & $29,6 \%$ \\
\hline $41-50$ & 11 & $6,5 \%$ \\
\hline 51 years and older & 7 & $4,2 \%$ \\
\hline Total & 169 & $100 \%$ \\
\hline \multicolumn{3}{|l|}{ GENDER } \\
\hline Male & 88 & $52,1 \%$ \\
\hline Female & 81 & $47,9 \%$ \\
\hline Total & 169 & $100 \%$ \\
\hline \multicolumn{3}{|l|}{ QUALIFICATIONS } \\
\hline Lower than Grade 12 & 16 & $9,4 \%$ \\
\hline Grade 12 & 67 & $39,4 \%$ \\
\hline Higher than Grade 12 (tertiary) & 86 & $51,2 \%$ \\
\hline Total & 169 & $100 \%$ \\
\hline \multicolumn{3}{|l|}{ LEVEL IN ORGANISATION } \\
\hline Supervisory level and lower & 136 & $81 \%$ \\
\hline Middle Management & 29 & $16,6 \%$ \\
\hline Senior Management & 4 & $2,4 \%$ \\
\hline Total & 169 & $100 \%$ \\
\hline
\end{tabular}


There is a relatively even distribution between male and female respondents $-52,1 \%$ male and $47,9 \%$ female. The qualifications were mostly on a grade 12 or a higher level. It was interesting to note that although most of the individuals were functioning at supervisory level or lower (81\%), 52\% of the individuals who participated had some form of qualification at a level higher than grade 12 .

\section{The measuring instrument}

The instrument used in this study is the Customer Intimacy section of the Culture Assessment Questionnaire (CAQ) that was developed by GATES ${ }^{1}$. The CAQ consists of three scales based on the three value disciplines described by Treacy and Wiersema $(1993,1995)$. The three scales identify the presence of a focus towards operational excellence, product leadership and customer intimacy in organisational cultures respectively. Only the scale aimed at the measurement of a customer intimacy culture was used in the current study.

All the items of the CAQ were stated in question format while the response scale format was a seven-point intensity scale, on which only the extreme poles were defined. The lowest rating of one indicates a low preference, while the top rating of seven indicates a high preference. The following ten dimensions were included in this scale (refer to Table 1 for a description of the dimensions):

- Dimension A: Personnel Strategy

- Dimension B: Organising

- Dimension C: Personnel Procurement

- Dimension D: Development

- Dimension E: Achievement

- Dimension F: Remuneration

- Dimension G: Strategy

- Dimension H: Core Values

- Dimension I: Core Abilities

- Dimension J: Business Model

On average, there were about ten items for each dimension in an attempt to tap into each sub-domain of a particular dimension.

There are no known comparative research findings published on the use of this instrument (or any similar instrument) in an organisational context. However, previous research has been completed to consider the measurement of value preferences among customers, and to evaluate empirically the measuring instrument in determining the value orientations of a customer base (cf. Dannhauser $\&$ Roodt, 2001).

\section{Research procedure}

The top management structure of the organisation was briefed in advance on the purpose of the study and permission was granted to access its staff on developmental paths, while on scheduled training. During the period in which sampling took place, all the individuals in the organisation at line, middle and top management levels were completing modular training specifically related to their planned individual development plans, thus ensuring that they all had an equal chance of being included in the sample.

Although all the individuals in the identified sample were briefed on the purpose of the study, participation was voluntary. Strict control was maintained over the completed questionnaires. The first author administered all the questionnaires to ensure consistency in the application process.

\section{Statistical analyses}

The collation of the data, the analyses thereof and the generation of results were conducted by the Statistical Consultation Service of the Rand Afrikaans University.

The analyses of the data were conducted in two broad phases. The first phase focused on the two levels of factor analyses and the iterative item analyses. The aim is first to determine the suitability of the item intercorrelation matrix for factor analysis. The goal of factor analysis is to determine a smaller number of common factors that help explain these correlations (Hair, Anderson, Tatham \& Black, 1998). Thus, the variables must be related to one another, preferably to a moderate degree, in order for the factor analysis to be appropriate. This may be done by using a variety of methods, including the Kaiser-Meyer-Olkin Index or Bartlett's test of sphericity.

The Kaiser-Meyer-Olkin Index procedure for determining the suitability of the correlation matrix for factor analysis involves the computation of the Kaiser-Meyer-Olkin (KMO) measure of sampling adequacy (MSA). The KMO is an index for comparing the magnitude of the observed correlation coefficients to the size of the partial correlation coefficients (Zillmer \& Vuz, 1995).

Bartlett's test of sphericity is designed to test the Null hypothesis, which states that variables in the correlation matrix are not related. As the value of the test increases and the associated significance level decreases, the likelihood increases that the Null hypothesis can be rejected and the alternative hypothesis accepted (i.e. the variables that constitute the correlation matrix are related). In contrast, as the value of the test decreases and the associated significance level increases, the likelihood that the Null hypothesis is true increases and, in turn, the alternative hypothesis must be rejected. The use of Bartlett's test of sphericity is recommended for analyses where sample size is relatively small (e.g. $\mathrm{n}=100)$ (Zillmer \& Vuz, 1995).

In the second phase of the analysis process, ANOVAs and t-tests were performed to determine whether there were any significant differences in culture mean scores for the different age groups, genders, qualification levels or levels in the organisation.

\section{RESULTS}

First phase of the data analyses

The results of the first level factor analyses are reported next.

\section{First level factor analyses}

Owing to the small sample size, an adjusted procedure for the first level factor analyses was used. This procedure entailed the parcelling of items in theoretical dimensions. The corresponding $\mathrm{KMO}$ coefficients for each dimension of the $\mathrm{CAQ}$ are reported in Table 3 and it seems that they are above and beyond acceptable levels. As displayed in Table 3 the obtained Bartlett's test values for each dimension of the CAQ are all statistically significant.

Based on the obtained KMO coefficients and Bartlett's test values, item intercorrelations and first level factor analyses followed by iterative item analyses were then performed on these item parcels (dimensions). This procedure of parcelling was followed in order to comply with the requirement of an optimal ratio (1:5) between the number of items and respondents (Bryant \& Yarnold, 1995). Owing to limited space, all these calculations will not be reported here.

Table 3 indicates that even though the overall dimensional representation is not sufficient to make valid decisions on reliability, the reliability analyses provide information needed to proceed with the factor analysis on the second level. Thus, from the results of the analyses, it is clear that all the dimensions yielded acceptable Cronbach Alphas indicating high internal consistencies.

\section{Second level factor analysis}

On the second level factor analysis, the sub-scores of the ten dimensions were intercorrelated. This intercorrelation matrix of 
sub-scores was also tested for the suitability for factor analysis, using the KMO measure of sampling adequacy and Bartlett's test. The obtained values (in Table 4) indicate that the matrix is suitable for further factor analysis.

\section{TABLE 3}

KMO MEASURES OF SAMPLING ADEQUACY, Bartlett's tests of Sphericity and Cronbach Alphas PER THEORETICAL DIMENSION OF THE CAQ

\begin{tabular}{lcccccc}
\hline Theoretical dimension Items & $\begin{array}{c}\text { Kaiser } \\
\text { Meyer } \\
\text { Olkin } \\
\text { MSA }\end{array}$ & & $\begin{array}{c}\text { Bartlett's } \\
\text { test }\end{array}$ & $\begin{array}{c}\text { Cronbach } \\
\text { Alphas }\end{array}$ \\
\hline Personnel Strategy & 10 & 0,677 & 108,891 & 3 & 0,000 & 0,8607 \\
Organising & 10 & 0,500 & 36,886 & 1 & 0,000 & 0,8334 \\
Personnel Procurement & 12 & 0,500 & 68,286 & 1 & 0,000 & 0,8712 \\
Development & 11 & 0,500 & 89,611 & 1 & 0,000 & 0,8887 \\
Achievement & 11 & 0,500 & 84,990 & 1 & 0,000 & 0,9131 \\
Remuneration & 13 & 0,500 & 46,770 & 1 & 0,000 & 0,9075 \\
Strategy & 13 & 0,722 & 180,505 & 3 & 0,000 & 0,9078 \\
Core values & 13 & 0,600 & 150,818 & 1 & 0,000 & 0,9385 \\
Core abilities & 12 & 0,600 & 91,390 & 1 & 0,000 & 0,8972 \\
Business model & 16 & 0,741 & 221,615 & 3 & 0,000 & 0,9295 \\
\hline
\end{tabular}

TABLE 4

KMO MEASURE OF SAMPLING ADEQUACY AND BARTLETT'S TEST FOR SPHERICITY OF THE UNREDUCED SUBSCORE INTERCORRELATION MATRIX OF THEORETICAL DIMENSIONS

\begin{tabular}{lcc}
\hline Kaiser-Meyer-Olkin Measure of Sampling Adequacy & 0,916 \\
Bartlett's Test of Sphericity & Approx. Chi-Square & 970,142 \\
& df & 45 \\
Sig. & 0,000 \\
\hline
\end{tabular}

After the sub-scores of the ten dimensions were intercorrelated, eigenvalues were calculated. A single factor was postulated, based on the obtained eigenvalues. The result of this calculation is illustrated in Table 5 .

TABLE 5

EIGENVALUES OF THE UNREDUCED SUBSCORE INTERCORRELATION MATRIX OF THEORETICAL DIMENSIONS

\begin{tabular}{lccc}
\hline & \multicolumn{3}{c}{ Initial Eigenvalues } \\
\hline Factor & Total & \% of Variance & Cumulative \% \\
\hline 1 & 6,932 & 69,322 & 69,322 \\
2 & 0,807 & 8,065 & 77,387 \\
3 & 0,553 & 5,531 & 82,918 \\
4 & 0,440 & 4,401 & 87,319 \\
5 & 0,339 & 3,389 & 90,708 \\
6 & 0,260 & 2,603 & 93,311 \\
7 & 0,212 & 2,120 & 95,431 \\
8 & 0,180 & 1,801 & 97,232 \\
9 & 0,146 & 1,459 & 98,691 \\
10 & 0,131 & 1,309 & 100,000 \\
Trace & 10,0 & & \\
\hline
\end{tabular}

Extraction Method: Principal Axis Factoring
Table 6 indicates that a single factor was extracted by using Principal Axis factoring. Four iterations were required for the solution to converge. All the dimensions indicate high loadings, varying between 0,88 and 0,75 on the single extracted factor.

TABLE 6

UNROTATED FACTOR MATRIX OF THEORETICAL DIMENSIONS

\begin{tabular}{lcc}
\hline Theoretical dimensions & Factor $\mathbf{1}$ & Communalities \\
\hline Strategy & 0,887 & 0,787 \\
Business model & 0,852 & 0,726 \\
Organising & 0,837 & 0,701 \\
Core abilities & 0,836 & 0,700 \\
Achievement & 0,813 & 0,661 \\
Personnel Procurement & 0,809 & 0,654 \\
Development & 0,795 & 0,632 \\
Core values & 0,770 & 0,593 \\
Personnel Strategy & 0,761 & 0,579 \\
Remuneration & 0,752 & 0,566 \\
\hline
\end{tabular}

With the extraction of the single factor indicated above, Table 7 shows the obtained sub-score means, variances and Cronbach Alphas. The overall internal consistency of the instrument is an acceptable 0,95 .

TABLE 7

RELIABILITY STATISTICS OF THE Culture Assessment Questionnaire

\begin{tabular}{lcccc}
\hline Factor & $\begin{array}{c}\text { Scale Mean if } \\
\text { factor deleted }\end{array}$ & $\begin{array}{c}\text { Scale Variance } \\
\text { if factor deleted }\end{array}$ & $\begin{array}{c}\text { Corrected factor- } \\
\text { total correlation }\end{array}$ & $\begin{array}{c}\text { Alpha if factor } \\
\text { deleted }\end{array}$ \\
\hline 1 & 43,6689 & 62,1649 & 0,7409 & 0,9463 \\
2 & 43,5838 & 63,0459 & 0,8162 & 0,9435 \\
3 & 44,0506 & 60,6372 & 0,7880 & 0,9444 \\
4 & 43,7260 & 61,6909 & 0,7775 & 0,9447 \\
5 & 43,7738 & 60,5178 & 0,7927 & 0,9442 \\
6 & 43,9274 & 62,2275 & 0,7322 & 0,9467 \\
7 & 43,9103 & 60,4041 & 0,8611 & 0,9410 \\
8 & 43,2700 & 62,3501 & 0,7433 & 0,9462 \\
9 & 43,7352 & 62,6876 & 0,8092 & 0,9436 \\
10 & 43,5944 & 62,1393 & 0,8242 & 0,9429 \\
\hline
\end{tabular}

Alpha $=0,9496 \quad$ Standardised item alpha $=0,9506$

The intercorrelations of the different theoretical dimensions are presented in Table 8 . It is clear that the correlations are fairly high (ranging from 0,53 to 0,84 ), suggesting that all these dimensions share some common variance. The obtained correlations confirm the convergent validity of the scale, because no specific dimension appears to be unrelated to, or divergent from, other dimensions of the scale.

Second phase of the data analyses

No significant differences were found (not reported here, owing to the non-significant nature of the results and limited space), which may raise questions about the discriminant validity of the measuring instrument, an important prerequisite (cf. Du Toit \& Roodt, 2003; Petkoon \& Roodt, 2004) that is often not dealt with in culture assessment instruments (cf. Ashkanasy et al., 2000). 
TABle 8

INTERCORRELATIONS OF CULTURE DIMENSIONS

\begin{tabular}{|c|c|c|c|c|c|c|c|c|c|c|c|}
\hline & & $\begin{array}{c}\text { Section A: } \\
\text { Personnel } \\
\text { Strategy }\end{array}$ & $\begin{array}{l}\text { Section B: } \\
\text { Organising }\end{array}$ & $\begin{array}{c}\text { Section C: } \\
\text { Personnel } \\
\text { Procurement }\end{array}$ & $\begin{array}{c}\text { Section D: } \\
\text { Development }\end{array}$ & $\begin{array}{l}\text { Section E: } \\
\text { Achievement }\end{array}$ & $\begin{array}{l}\text { Section F: } \\
\text { Remuneration }\end{array}$ & $\begin{array}{l}\text { Section G: } \\
\text { Strategy }\end{array}$ & $\begin{array}{l}\text { Section } \mathrm{H} \text { : } \\
\text { Core values }\end{array}$ & $\begin{array}{l}\text { Section I: } \\
\text { Core abilities }\end{array}$ & $\begin{array}{c}\text { Section J: } \\
\text { Business } \\
\text { model }\end{array}$ \\
\hline Section A: Personnel & Pearson Correlation & 1 & 0,780 & 0,678 & 0,586 & 0,673 & 0,554 & 0,625 & 0,569 & 0,573 & 0,638 \\
\hline Strategy & $\mathbf{N}$ & 165 & 158 & 153 & 155 & 155 & 146 & 151 & 152 & 146 & 144 \\
\hline Section B: & Pearson Correlation & 0,780 & 1 & 0,721 & 0,657 & 0,691 & 0,605 & 0,684 & 0,644 & 0,700 & 0,700 \\
\hline Organising & $\mathbf{N}$ & 158 & 163 & 153 & 153 & 154 & 146 & 153 & 151 & 145 & 143 \\
\hline Section C: & Pearson Correlation & 0,678 & 0,721 & 1 & 0,751 & 0,672 & 0,561 & 0,650 & 0,539 & 0,657 & 0,608 \\
\hline $\begin{array}{l}\text { Personnel } \\
\text { Procurement }\end{array}$ & $\mathbf{N}$ & 153 & 153 & 158 & 148 & 148 & 140 & 145 & 146 & 142 & 140 \\
\hline Section D: & Pearson Correlation & 0,586 & 0,657 & 0,751 & 1 & 0,801 & 0,636 & 0,700 & 0,534 & 0,678 & 0,613 \\
\hline Development & $\mathbf{N}$ & 155 & 153 & 148 & 159 & 155 & 142 & 147 & 147 & 140 & 139 \\
\hline Section E: & Pearson Correlation & 0,673 & 0,691 & 0,672 & 0,801 & 1 & 0,633 & 0,711 & 0,586 & 0,647 & 0,694 \\
\hline Achievement & $\mathbf{N}$ & 155 & 154 & 148 & 155 & 159 & 144 & 147 & 147 & 141 & 139 \\
\hline Section F: & Pearson Correlation & 0,554 & 0,605 & 0,561 & 0,636 & 0,633 & 1 & 0,724 & 0,682 & 0,685 & 0,662 \\
\hline Remuneration & $\mathbf{N}$ & 146 & 146 & 140 & 142 & 144 & 150 & 142 & 142 & 137 & 135 \\
\hline \multirow[t]{2}{*}{ Section G: Strategy } & Pearson Correlation & 0,625 & 0,684 & 0,650 & 0,700 & 0,711 & 0,724 & 1 & 0,705 & 0,813 & 0,781 \\
\hline & $\mathbf{N}$ & 151 & 153 & 145 & 147 & 147 & 142 & 156 & 151 & 145 & 142 \\
\hline Section H: & Pearson Correlation & 0,569 & 0,644 & 0,539 & 0,534 & 0,586 & 0,682 & 0,705 & 1 & 0,767 & 0,804 \\
\hline Core values & $\mathbf{N}$ & 152 & 151 & 146 & 147 & 147 & 142 & 151 & 157 & 146 & 142 \\
\hline Section I: & Pearson Correlation & 0,573 & 0,700 & 0,657 & 0,678 & 0,647 & 0,685 & 0,813 & 0,767 & 1 & 0,843 \\
\hline Core abilities & $\mathbf{N}$ & 146 & 145 & 142 & 140 & 141 & 137 & 145 & 146 & 151 & 140 \\
\hline Section J: & Pearson Correlation & 0,638 & 0,700 & 0,608 & 0,613 & 0,694 & 0,662 & 0,781 & 0,804 & 0,843 & 1 \\
\hline Business model & $\mathbf{N}$ & 144 & 143 & 140 & 139 & 139 & 135 & 142 & 142 & 140 & 147 \\
\hline
\end{tabular}

Correlations are significant at the 0,01 level (2-tailed).

\section{DISCUSSION}

The study was conducted in two broad phases. The first phase focused on the factor analyses on two levels - first and second level factor analysis and reliability analysis. The results indicated a robust internal consistency for the questionnaire $(0,95)$ as it clearly displays the necessary elements to measure what it is supposed to measure. Furthermore, high intercorrelations between theoretical dimensions provide evidence for the convergent validity of the scale and eliminate any evidence for the divergent validity of any dimension.

A first level factor analysis was completed and high internal consistency levels were found on all ten dimensions of the survey. This confirms the factorial validity as well as the face and content validity of the instrument. As the sampling group was relatively small, it was decided to follow a process of parcelling items on the theoretical dimensions and factor analyse dimensions separately to determine the internal reliability of each dimension separately. A second level factor analysis was completed and one factor was extracted leading to a single scale with a reliability coefficient of 0,95 . The study indicates that the Customer Intimacy section of the Culture Assessment Questionnaire (CAQ) can be used to determine the customer intimacy culture reliably in the value discipline context. These findings support the first objective of the study.

The dimensions in the measurement tool correlate directly with the core elements of strategically directed cultures within the organisation (refer to Table 1). They can be used to measure reliably the current Customer Intimacy orientation and to identify focus areas for change or development interventions.
The research of Treacy and Wiersema $(1993 ; 1995)$ indicates that total organisational strategic focus (people, process and product/service) is needed to address fully the customer's value adding requirements. However, the other value disciplines cannot be discarded and should at least be of an industry standard.

\section{Implications for organisation strategy and culture}

The strategic link to organisational effectiveness and competitiveness is also based on meeting and exceeding customers' needs and expectations. To enable organisations to do so, they need to understand what the value orientation of their specific customer base is. More importantly, they also need to focus continuously on the strategic alignment of their people, processes and products to ensure that they create and maintain an organisational strategy and culture that can sustain an achievement of the required value orientation in an everchanging strategic organisational environment.

The use of the CAQ to assess the presence of the customer intimacy value orientation can assist the organisational leadership in their strategic planning and leadership processes in that it indicates the presence of the orientation and identified areas of development/change required for success.

Additional application areas could also include:

- Assisting organisations with the identification of problem areas in their customer intimacy orientation and the identification of focus areas for improvement.

- Assisting in the clarification of overall strategic focus areas in terms of customer service. If more organisations in South Africa focused on these areas the perceptions of service delivery in this country could be improved. 
- Given the results of The World Competitiveness Report (Garelli, 1999), it could become one of the main diagnostic tools used to plan improvements for service delivery.

Limitations of the study

The limitations of this study may be the following:

- The study was conducted only in a single organisation in the entertainment industry.

- Due to the small sample size, an adapted procedure for factor analyses was conducted based on specific assumptions about the relationships between variables.

- The findings of this study are not intended to make generalisations about the industry, but are focused on the evaluation of the instrument.

- It appears as though the instrument lacks discriminant validity, an issue that needs to be investigated more closely.

The above does not however discount the fact that the results of the study indicate that the measurement tool can be used to determine the presence of a Customer Intimacy value discipline reliably in an organisational context.

\section{Suggestions for further research}

It is suggested that further research should be conducted to test the three culture assessment instruments of all three value disciplines where organisations have been identified a priori in terms of their value orientation. The objective of the study would then be to test whether the instruments could classify the organisations according to their value orientation.

Organisational leadership should focus strategically on the required customer preference, while still achieving parity in the other two value disciplines. The same study should be repeated, evaluating all three scales in the same environment, as this would provide a more holistic assessment of the presence of, and development areas in, each of the value disciplines.

\section{Value of the study}

The results of the study indicate that the instrument can be used to measure culture accurately in the context of the value discipline of Customer Intimacy. Upon further evaluation of the results achieved, the measuring instrument could become a valued tool to be used in preparing the organisation for success in a world of ever-changing customer demands. The tool could even be used as a guideline for Human Resources Development practitioners to identify the development of the competency profile for the organisation.

Broader use of the measurement tool could ultimately heighten the focus on the level of customer service in South African organisations, and thus improve South Africa's ranking on the international markets in terms of competitiveness related to customer service.

\section{Conclusion}

Based on the empirical findings, it can be concluded that the study achieved its objectives. It appears that the instrument can validly and consistently assess a company's customer intimacy culture. It however appears that the instrument cannot discriminate between culture mean scores of different groups created by categorising groups according to biographical variables.

\section{REFERENCES}

Ashkanasy, N.M., Wilderom, C.P.M. \& Peterson, M.F. (Eds.) (2000). Handbook of organizational culture and climate. California: Sage Publications, Inc.

Bryant, F.B. \& Yarnold, P.R. (1995). Principal components analysis and exploratory and confirmatory factor analysis. In
Grimm, L.G. \& Yarnold, P.R. (Eds). Reading and understanding multivariate analysis. American Psychological Association Books.

David, F.R. (1999). Strategic Management Concepts. (7th Edition). New Jersey: Prentice-Hall Inc.

$\mathrm{Du}$ Toit, W.F. (2003). The discriminant validity of a culture assessment instrument: A comparison of company cultures. Unpublished D Phil thesis. Johannesburg: Rand Afrikaans University.

Du Toit, W. \& Roodt, G. (2003). The discriminant validity of the Culture Assessment Instrument: A comparison of company cultures. SA Journal of Human Resource Management, 1 (1), 77-84

Erwee, R., Lynch, B., Millitt, B., Smith, D. \& Roodt, G. (2001). Cross-cultural equivalence of the organizational culture survey in Australia. Journal of Industrial Psychology, 27 (3), $7-12$.

Exner, J.E. (Ed.) (1995). Issues and methods in Rorscach research. California: Sage Publications.

French, J.E. (1995). Value disciplines in community bank management. Bankers Magazine, January - February, 44-48.

Garelli, S. (1999). World Competitiveness Report: 1999. Geneva, Switzerland: EMF Foundation.

Grimm, L.G. \& Yarnold, P.R. (Eds). Reading and understanding multivariate analysis. American Psychological Association Books.

Gubman, E.L. Aligning people strategies with customer value. Compensation \& Benefits Review, January - February, 15-22.

Hair, J.F., Anderson, R.E., Tatham, R.L. \& Black, W.C. (1998). Multivariate data analysis. New Jersey: Prentice Hall Inc.

Howell, D.C. (1995). Fundamental Statistics for the Behavioural Science. California: Wadsworth Publishing Company.

Huysamen, G.K. (1996). Methodology for the Social and Behavioural Sciences, South Africa: International Thomson Publishing.

Martins, N. (1989). Organisasiekultuur in 'n finansiele instelling [Organisation culture in a financial institution]. Unpublished D Phil thesis. Pretoria: University of Pretoria.

Petkoon, L. (2003). The discriminant validity of a culture assessment instrument: a comparison of company sub-cultures. Unpublished D Phil thesis. Johannesburg: Rand Afrikaans University.

Petkoon, L. \& Roodt, G. (2004). The discriminant validity of the culture assessment instrument: A comparison of company sub-cultures. SA Journal of Industrial Psychology, 30 (1), 74-82.

Schein, E.H. (1985). Organisational culture and leadership. San Francisco: Jossey-Bass.

Schein, E.H., DeLisi, P., Kampas, P. \& Sonduck, M. (2003). $D E C$ is dead, long live DEC: The lasting legacy of Digital Equipment Corporation. San Francisco: Berrett-Koehler Publishers.

Smith, S. (2003). An evaluation of response scale formats of the culture assessment instrument. Unpublished D. Phil. thesis. Johannesburg: Rand Afrikaans University.

Treacy, M. \& Wiersema, F. (1993). Customer Intimacy and other value disciplines. Harvard Business Review, February, 84-93.

Treacy, M. \& Wiersema, F. (1995). How market leaders keep their edge. Fortune, 131 (2), 52-57.

Treacy, M. \& Wiersema, F. (1995). The Discipline of Market Leaders. London: Harper Collins.

Treacy, M. (1995). You need a value discipline - but which one? Fortune, 131 (7), 17.

Treacy, M. (1998) Value leadership, strategic agility and organisational greatness. Retrieved from the world wide web on: www.booksinternational.co/micheal_treacy,htm.

Zemke, R. (1993). Creating customer value. Training, 30 (9), 45-54.

Zillmer, E.A. \& Vuz, J.K. (1995). Factor analysis with Rorscach data. In J.E. Exner (Ed.) Issues and methods in Rorscahch research. California: Dage Publications. 